\title{
UVEITIS*
}

\section{A CLINICAL AND STATISTICAL SURVEY}

\author{
BY
}

\section{GEORGE BENNETT}

\section{Southampton}

THE most popular classification of the uveites remains that expounded by Woods $(1947,1949,1951 a)$ into granulomatous types (due to systemic granulomatoses such as tuberculosis, spirochaetosis, brucellosis, toxoplasmosis, sarcoidosis, or virus infection) and non-granulomatous types due to bacterial (chiefly streptococcal) allergy arising from septic foci.

There is now a tendency to reduce the importance of syphilis and tuberculosis (François, 1950; Sorsby, 1951; Vesterdal, 1951, 1952; Gasteiger, 1952; Alvaro, 1954) and to place more emphasis on toxoplasmosis (Wilder, 1952; Woods and others, 1954) or on certain proved or suspected viral diseases (Cavara, 1950; Jaffe, 1950; Schreck, 1951; Sorsby, 1951; Remky, 1953; Tanner, 1954) in the case of granulomatous uveitis. Although the focal-sepsis-bacterial-allergy theory has been largely abandoned by the rheumatologist (Empire Rheumatism Council, 1950; Copeman, 1955) and by some ophthalmologists (François, 1950; Sorsby, 1951; Vesterdal, 1952), it still retains a strong fascination for others (Woods, 1949, 1953; Müller, 1950; Ridley and Harley, 1951; Alvaro, 1954). Yet at best, we must admit the case for this concept to remain " unproven" (Burnet, 1954).

Faced by the present ignorance of the basic causes of much uveitis, the author has devised a classification based on three positive associations, which may or may not possess aetiological significance. This avoids the various analogies and presumptions inherent in other schema, and has been applied to 332 cases of "primary" uveitis investigated by the author:

Group A Collagenous Disease.-66 (20 per cent.).

Previous rheumatic fever $\ldots \quad 5 \quad$ (4 female, 1 male)

Ankylosing spondylitis $\quad \ldots \quad 34 \quad(28$ male, 6 female)

Rheumatoid arthritis $\quad \ldots \quad 27$ (24 female, 3 male)

Group B Local Virus Infection.-127 (38 per cent.; 77 male, 50 female)

Group C Systemic Disease.-Granulomatous uveitis ... 15 (4.5 per cent.; 7 male, 8 female)

$\begin{array}{lcccccc}\text { Sarcoidosis } & \ldots & \ldots & \ldots & \ldots & \ldots & 7 \\ \text { Canicola fever } & \ldots & \ldots & \ldots & \ldots & \ldots & 1 \\ \text { Syphilis (followed by } & \text { interstitial } & \text { keratitis) } & \ldots & 2 \\ \text { Influenza } & \ldots & \ldots & \ldots & \ldots & \ldots & 2 \\ \text { Varicella } & \ldots & \ldots & \ldots & \ldots & \ldots & 1 \\ \text { Toxoplasmosis } & \ldots & \ldots & \ldots & \ldots & \ldots & 2\end{array}$

* Received for publication August 3, 1955. 
Group D Unclassified.-124 (37.5 per cent.; 65 male, 59 female).

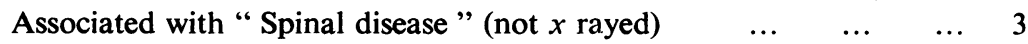

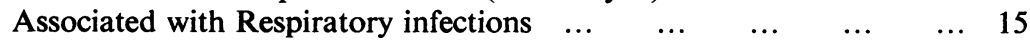

$\begin{array}{lllllllll}\text { Associated with Diabetes } & \ldots & \ldots & \ldots & \ldots & \ldots & \ldots & \ldots & 3\end{array}$

$\begin{array}{lllllllll}\text { Associated with Scleroderma } & \ldots & \ldots & \ldots & \ldots & \ldots & \ldots & 1\end{array}$

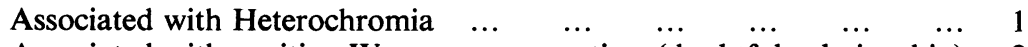

Associated with positive Wassermann reaction (doubtful relationship) 2

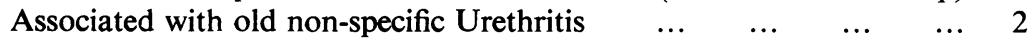

None of the associations in Group $\mathrm{D}$ could be said to have positive aetiological value, though they are suggestive in some instances. Thus the "spinal disease" and scleroderma cases probably belong to the "collagenous" group whilst the others largely represent viral infections. It is interesting to note that 102 of these " unclassified" patients had never been examined at an early stage of an attack (i.e. within a minimum of 4 days from the onset). It is possible that some would have been assigned to Group B, and that, given full investigation and observation of each case, many could have been allotted to the other groups.

The majority were affected predominantly in the anterior segment (" iridocyclitics"), a number could be called "irido-choroiditics", and thirteen (4 per cent.) showed localization of inflammation chiefly to the posterior segment ("choroiditics"). No definite cause could be found for eleven of these thirteen; the other two were thought to be due to the toxoplasma.

Certain explanatory notes are required:

(i) By " primary" uveitis we mean generally that no other ocular lesion is concurrent; in addition, sympathetic, traumatic and phaco-anaphylactic uveites are excluded.

(ii) Groups A, C, and D are self-explanatory, but in Group B are included eyes which at some time, before or after the uveitis, have shown evidence (viz. herpetic, abacterial keratitis or conjunctivitis; superficial punctate keratitis, or epidemic kerato-conjunctivitis) of virus infection. Such evidence often goes unrecognized; it may be trivial and evanescent, may occur early before the patient seeks advice, and may not appear in recurrences as the virus may then be resident within the uveal tract in symbiosis (Braley, 1952; Dalrymple-Champneys, 1955). The virus may be liberated, if dormant, or its penetration facilitated by trauma or by high cortico-steroid levels such as obtain in shock, systemic infection, anxiety, myxoedema, pregnancy, or hormone therapy (Gundersen, 1936; Selye, 1950; Dubos, 1954; Braley, 1952; Bayliss, 1955). The danger of the exhibition of these hormones in various infections is well attested (e.g. Woods and Wood, 1950, 1952; Braley and Alexander, 1953; Thygeson, 1953), as is the relationship of viral eye lesions to trauma (Sanders, 1942; Berliner, 1943; Thygeson, 1951; Braley, 1952).

We might here note that uveitis is rarely associated with rheumatic fever (Duke-Elder, 1940; Rudolph, 1945) which, unlike rheumatoid arthritis, is undoubtedly a sequel to streptococcal infection. It is possible that our five cases were of acute rheumatoid or Still's disease, as they were not seen in the active stage.

Finally, it appears that while this survey takes account chiefly of the positive findings of the investigations, it would not be out of place to mention the negative side. Thus no cases showed clinical or serological evidence of brucellosis or infectious mononucleosis, and only one showed evidence of gonorrhoea; as we shall see, only five cases showed a positive 
Wassermann reaction, and the relationship of this to the uveitis was usually in doubt. No case could definitely be described as tuberculous.

We may now proceed to the categorical analysis of the 332 cases.

(1) Laterality (Table I).-We assume that Groups B and C are of infective aetiology, one local and the other systemic in nature. We should therefore expect Group $\mathrm{C}$ to be usually bilateral, whereas B might be uni- or bilateral. The herpetic virus usually affects only one eye (Thygeson, 1951), whereas superficial punctate keratitis often affects both (Maumenee and others, 1945; Cockburn, 1954), and may be due to the herpes simplex or a related TABLE I LATERALITY OF AFFECTION

\begin{tabular}{|c|c|c|c|}
\hline \multirow{2}{*}{ Group } & \multicolumn{2}{|c|}{ Unilateral } & \multirow{2}{*}{ Bilateral } \\
\hline & No. & $\%$ & \\
\hline $\begin{array}{l}\text { A } \\
\text { B } \\
\text { C } \\
\text { D }\end{array}$ & $\begin{array}{r}42 \\
91 \\
2 \\
76\end{array}$ & $\begin{array}{l}64 \\
72 \\
13 \\
61\end{array}$ & $\begin{array}{l}24 \\
36 \\
13 \\
48\end{array}$ \\
\hline Total & 211 & 64 & 121 \\
\hline
\end{tabular}
virus capable of causing uveitis. Thus in Group B 28 patients ( 22 per cent.) suffered from definite typical superficial punctate keratitis at some time (Table II).

TABLE II

TYPES OF VIRUS LESION IN GROUP B

\begin{tabular}{|c|c|c|c|c|c|c|c|c|}
\hline \multicolumn{2}{|c|}{ Total Patients } & \multirow{3}{*}{\multicolumn{2}{|c|}{ Type of Corneal Lesion }} & \multicolumn{4}{|c|}{ Uveitis } & \multirow{3}{*}{ Total } \\
\hline \multirow{2}{*}{ No. } & \multirow{2}{*}{$\%$} & & & \multicolumn{2}{|c|}{ Unilateral } & \multicolumn{2}{|c|}{ Bilateral } & \\
\hline & & & & No. & $\%$ & No. & $\%$ & \\
\hline 28 & 22 & S.P.K. & $\begin{array}{l}\text { Unilateral } \\
\text { Bilateral }\end{array}$ & $\begin{array}{r}15 \\
2\end{array}$ & $\begin{array}{r}54 \\
7\end{array}$ & $\overline{11}$ & $\overline{39}$ & $\begin{array}{l}15 \\
13\end{array}$ \\
\hline 99 & 78 & $\begin{array}{c}\text { Herpetic or } \\
\text { other }\end{array}$ & $\begin{array}{l}\text { Unilateral } \\
\text { Bilateral }\end{array}$ & $\begin{array}{r}69 \\
5\end{array}$ & $\begin{array}{r}70 \\
5\end{array}$ & $\overline{25}$ & $\overline{25}$ & $\begin{array}{l}69 \\
30\end{array}$ \\
\hline
\end{tabular}

Of these, superficial punctate keratitis was noted in both corneae of thirteen, and in eleven was associated with bilateral uveitis. It was unilateral in fifteen, and in none of these was uveitis bilateral. In both unilateral and bilateral cases it frequently recurred.

One of the cases of bilateral superficial punctate keratitis was associated with herpes labialis, and another with exfoliative dermatitis and subungual warts. Two of the cases of unilateral superficial punctate keratitis gave histories of dendritic ulceration, two more had previously had zoster of the trunk, and one other suffered a contralateral 5th nerve zoster 12 months before. The case of exfoliative dermatitis had had multiple attacks varying from simple conjunctivitis to bilateral hypopyon uveitis with hypertension, over a period of 20 years; his wife suffered with recurrent herpes febrilis facialis. The skin lesions usually accompanied the ocular disorders. The remaining 99 cases in Group B (78 per cent.) had at some time suffered either dendritic, disciform, abacterial, or nonspecific corneal lesions or simple conjunctivitis as defined earlier; 25 of these had 
bilateral uveitis ( 25 per cent.) as opposed to the eleven ( 39 per cent.) of the superficial punctate keratitis cases. Though these proportions are without statistical significance $(P>0.05)$, they do suggest that bilateral disease is more likely to follow superficial punctate keratitis lesions than herpetic lesions; on the other hand it is also likely that some superficial punctate keratitis is related to herpes febrilis and zoster. It is frequently stated that superficial punctate keratitis does not recur and does not cause iritis, but our series refutes these assertions, whatever the virus may be. Widespread viral disease was suggested in several cases. The corneal lesions were frequently evanescent, and might be present for only 2 or 3 days; thus they were presumably missed in the first two attacks of bilateral uveitis in a woman who suffered no systemic disease past or present, save a mild non-specific urinary infection 6 years before, but noted, when she reported soon after the onset of the third attack, to be replaced by keratic precipitates in less than a week. To return to the question of laterality, we see that 91 (72 per cent.) of Group B are unilateral, almost the same percentage, though not the same cases, as that of uveitis associated with lesions other than superficial punctate keratitis. On the other hand only two cases (13 per cent.) in Group $\mathrm{C}$ show affliction of only one eye. One of these was associated with influenza and could have been a herpetic infection; it was not seen early and enjoyed a rather rapid resolution. These proportions show a significant difference $(P<0.05)$. In the "collagenous" Group A, 42 cases (64 per cent.) were unilateral; this proportion does not vary significantly from that in Group B $(P>0 \cdot 05)$. The heterogenous " unclassified" Group D shows unilateral disease in 76 cases (61 per cent.). If this group were composed of cases of Groups A, B, C aetiology mixed, in similar proportions, each minor Group A, B, and C showing the laterality proportions of the major group, we should calculate an expected unilateral incidence for approximately 65 per cent. of individuals, which agrees fairly well with that found in practice.

(2) Sex.-The frequently attested sexual preferences of rheumatoid arthritis and ankylosing spondylitis are shown again here (Table III). Rheumatoid arthritis occurred in only three males and 24 females, whereas ankylosing spondylitis occurred in 28 males and six females. A few of the males and most of the females in the ankylosing spondylitis group showed rheumatoid changes in the peripheral joints in

TABLE III

SEX RATIOS

\begin{tabular}{c|c|c|c}
\hline \multirow{2}{*}{ Group } & \multicolumn{2}{|c|}{ Male } & \multirow{2}{*}{ Female } \\
\cline { 2 - 3 } & No. & $\%$ & \\
\hline A & 32 & 48 & 34 \\
B & 77 & 61 & 50 \\
C & 7 & 47 & 8 \\
D & 65 & 52 & 59 \\
\hline Total & 181 & 55 & 151 \\
\hline
\end{tabular}
addition to the pathology in the joints of the axial skeleton. Four of the five patients with a history of rheumatic fever were females. Combined to give the collagenous Group A, these figures show almost equal representation of the sexes ( 32 male ( 48 per cent.), 34 female). The "viral "Group B shows

an excess of males $(77,61$ per cent.) over females (50). This we should expect from the higher frequency of herpetic and superficial punctate keratitis infections in males possibly due to their greater liability to trauma (Sanders, 1942; Hogan and Crawford, 1942; Thygeson, 1943 and 1953; Feigenbaum and others, 1945) or 
other "occupational" disease, such as bronchitis and sinusitis, which affects males predominantly (q.v.). This proportional difference does not vary however, significantly from the 50:50 distribution or that shown by the "collagenous" group $\left(\chi_{2}=2 \cdot 14, n=1, P=0 \cdot 1-0 \cdot 2\right)$. The granulomatous Group $C$ also shows almost equal sex distribution (seven males, eight females), as does the unclassified Group D (52 per cent. males).

(3) Age Distribution.-The rarity of uveitis in children under 15 years is confirmed by this study. Only seven cases can be described in this series, giving $2 \cdot 1$ per cent., as compared with $2 \cdot 2$ per cent. in Denmark (Blegvad, 1941), and 5.8 per cent. under the age of 16 in U.S.A. (Kimura and others, 1954). Two of the author's cases were of toxoplasmosis, two were herpetic, and three were of unknown aetiology, one being associated with "pneumonia". In four the posterior segment was chiefly affected, in three the anterior. Three were unilateral (the "pneumonic", one of the herpetics, and one of the choroidites of unknown aetiology), four were bilateral. Four were female, three male. The extreme rarity of uveitis between the ages of 2 and 15 years (four cases herein) makes fascinating material for speculationas indeed does that of infections such as tuberculosis, brucellosis, enteritis, bronchitis, and pneumonia (see DalrympleChampneys, 1955; Dubos, 1951). Considering all TABLE IV cases, 155 (47 per cent.) were aged less than 40 years when suffering their first attack; the remaining 177 (53 per cent.) were aged 40 or over. The distribution for each Group is shown in

TABLE V

ERYTHROCYTE SEDIMENTATION RATES

(mm./hr Westergren)

\begin{tabular}{c|c|c|c|c}
\hline \multirow{2}{*}{ Group } & \multicolumn{2}{|c|}{ Greater than $10 \mathrm{~mm}}$. & \multirow{2}{*}{$10 \mathrm{~mm}$. or Less } & Total \\
\cline { 2 - 3 } & No. & $\%$ & & \\
\hline A & 28 & 80 & 7 & 35 \\
B & 19 & 33 & 39 & 58 \\
C & 6 & 86 & 1 & 7 \\
D & 25 & 42 & 34 & 59 \\
\hline Totals & 78 & 49 & 81 & 159 \\
\hline
\end{tabular}

Table IV, taking age 40 as an arbitrary dividing line.

We see that behaviour in Groups A, B, and D is very similar, approximately equal numbers falling above and below this line, but the majority (80 per cent.) of Group C cases occur at ages under 40. This proportion differs significantly from that (42 per cent.) for the Group B cases $(P<0 \cdot 05)$.

(4) Erythrocyte Sedimentation Rates. - The non-specific interpretation of this test is now admitted by all authorities. Table $\mathrm{V}$ shows that the rate is higher in cases of uveitis associated with systemic disease than in those with purely ocular conditions. 
The local infections of Group B show a significantly lower proportion $(P<0 \cdot 05)$ of cases with erythrocyte sedimentation rates less than $10 \mathrm{~mm}$. per $\mathrm{hr}$ than those in Groups A or $C^{*}$. Group D is in the intermediate position, which reflects its mixed composition. If we again consider Group $\mathrm{D}$ to consist of $\mathrm{A}, \mathrm{B}$, and $\mathrm{C}$ cases in the same ratio showing erythrocyte sedimentation rate levels equivalent to those in each group as in Table $\mathrm{V}$, we may predict the proportion of Group D cases which have an erythrocyte sedimentation rate of less than $10 \mathrm{~mm}$./hr. This works out at approximately 51 per cent.- not greatly varying from the value of 42 per cent. obtained clinically. These findings tend to reinforce the aetiological conception of uveitis adopted herein.

(5) Focal Infection.-The results of radiological examinations of the chest, jaws, and sinuses are shown in Table VI (221 patients).

TABLE VI

RESULTS OF RADIOLOGICAL INVESTIGATIONS

\begin{tabular}{|c|c|c|c|}
\hline$X$ Rays & Chest & Jaws & Sinuses \\
\hline $\begin{array}{l}\text { Normal } \\
\text { Pathological ... }\end{array}$ & $\begin{array}{r}180 \\
22 \text { ( } 11 \text { per cent.) }\end{array}$ & $\begin{array}{r}119 \\
28 \text { (19 per cent.) }\end{array}$ & $\begin{array}{r}125 \\
43 \text { (26 per cent.) }\end{array}$ \\
\hline Totals & 202 & 147 & 168 \\
\hline
\end{tabular}

The normal chest $x$ rays include three cases of inactive tuberculosis greater than an old primary complex.

The abnormal chest $x$ rays included the following groups:

$\begin{array}{llllrl}\text { Chronic bronchitis and emphysema } & 16 & \text { (8 per cent.) } \\ \text { Sarcoidosis ... } & \ldots & \ldots & \ldots & 5 & \text { ( } 2 \frac{1}{2} \text { per cent.) } \\ \text { Active tuberculosis } & \ldots & \ldots & \ldots & 1 & \text { ( } \frac{1}{2} \text { per cent.) }\end{array}$

The figure of 8 per cent. for chronic bronchitis probably obtains for any industrial population in the U.K. Thus Fry (1954) gives a minimal figure of $2 \cdot 8$ per cent. for a I_ondon urban population, and Stuart-Harris (1954) a figure of

TABLE VII

DISTRIBUTION OF POSITIVE CHEST $X$ RAYS

\begin{tabular}{cccc}
\hline Group & $\begin{array}{c}\text { Number } \\
\text { Positive }\end{array}$ & $\begin{array}{c}\text { Per cent. } \\
\text { of Group }\end{array}$ & Significance \\
\cline { 2 - 3 } A & 4 & 10 \\
B & 9 & 13 \\
C & 5 & 38 & \\
D & 4 & 5 & 11
\end{tabular}

$17 \cdot 2$ per cent. for males in a Sheffield industrial organization. Similarly, various radiological and other surveys have revealed a latent active pulmonary tuberculosis element in at least 0.5 per cent. of the population in England and Wales. Thus Springett (1951) gives 0.3-0.4 per cent., Stewart and Hughes (1951) 0.5 per cent., Cochrane and others (1952) $0 \cdot 75-1 \cdot 0$ per cent., Stalker (1954) $0 \cdot 12-0 \cdot 4$ per cent., and the Minister of Health (Hansard, 1952) quoted 0.67 per cent. for this region, in reply to a question in the House of Commons. The average of these figures is 0.53 per cent.

Only the sarcoid figures are of any importance here (Table VII).

* The Westergren technique is used: $10 \mathrm{~mm}$. is taken arbitrarily as the upper level of the "normal" 
Of the 28 cases showing dental abnormality (not counting simple caries), 23 had apical infection and five had buried roots. The incidence of caries and pyorrhoea is so high in Great Britain that we cannot give it any aetiological significance, and must concentrate on the more deep-seated and insidious types of dental disease.

The distribution and behaviour of our 28 cases and the effects of dental treatment when carried out are shown in Table VIII. The proportional differences between Group A and B are not significant $(P>0 \cdot 05)$. Group B uveitis relapsed even after treatment, suggesting that infection does not derive from the teeth in these cases. Several patients had no dental treatment yet did not relapse, some over long periods. François (1950) is doubtful whether uveitis is at all related to dental sepsis, as is Hughes (quoted by Woods, 1948), and Doggart (1949). The Empire Rheumatism Council Report (1950) showed that controls have as much dental infection as rheumatoid arthritics. Vesterdal (1951) obtained no ocular benefit from dental treatment in uveitis.

TABLE VIII

DENTAL DISEASE

\begin{tabular}{c|c|c|c|c|c|c}
\hline \multirow{2}{*}{ Group } & \multicolumn{3}{|c|}{ Treatment and Ocular Results } & \multirow{2}{*}{ Total } & Per cent. \\
in Group \\
\cline { 2 - 6 } & Treated & Relapsed & Not Treated & Relapsed & & \\
\hline A & 1 & - & 3 & 1 & 4 & 13 \\
B & 5 & -2 & 1 & 1 & 13 & 25 \\
C & -2 & 1 & 8 & - & 1 & 25 \\
D & 2 & 20 & 2 & 28 & 17 \\
\hline Totals & 8 & 3 & 20 & - \\
\hline
\end{tabular}

Finally, we may consider sinus disease. Radiological sinus opacity is so common in Great Britain as to be almost a condition of normality. It usually indicates past or present mucosal thickening or excessive secretion; pus, indicated by a fluid level and all the signs of bacterial infection, is not commonly present. The author examined the films of all cases $x$ rayed for suspected intra-ocular foreign bodies over 2 years. Of 42 patients, nineteen ( 45 per cent.) showed varying degrees of opacification of the sinuses, but few had any signs or symptoms of disease. This is much in excess of the 26 per cent. of our uveitis cases with positive $x$-ray pictures. Hughes found that sinus disease could be shown in 12 per cent. of his uveitis cases, and dental sepsis in 25 per cent.; similar proportions were obtained with a series of patients suffering from cataract. Table IX (overleaf) shows that the positive $x$ rays in our series were distributed fairly evenly throughout the various groups.

Those requiring and receiving treatment by a rhinologist (seven cases) as frequently suffered a relapse of uveitis as those who had no treatment, whatever the grouping. It is interesting to note that twelve of these cases also suffered from chronic bronchitis, and eight had definite dental sepsis as defined earlier. Thus 
TABLE IX

DISTRIBUTION OF CASES OF UVEITIS WITH POSITIVE SINUS $X$ RAYS

\begin{tabular}{|c|c|c|c|c|c|c|c|c|}
\hline \multirow{2}{*}{ Group } & \multirow{2}{*}{$\begin{array}{l}\text { Per cent. } \\
\text { in each } \\
\text { Group }\end{array}$} & \multirow{2}{*}{$\begin{array}{l}\text { Treat- } \\
\text { ment } \\
\text { required }\end{array}$} & \multirow{2}{*}{ Relapsed } & \multirow{2}{*}{$\begin{array}{l}\text { No } \\
\text { treat- } \\
\text { ment }\end{array}$} & \multirow{2}{*}{ Relapsed } & \multirow{2}{*}{$\begin{array}{l}\text { Chronic } \\
\text { Bronchitis } \\
\text { also }\end{array}$} & \multicolumn{2}{|c|}{ Totals } \\
\hline & & & & & & & No. & $\%$ \\
\hline $\begin{array}{l}\text { A } \\
\text { B } \\
\text { C } \\
\text { D }\end{array}$ & $\begin{array}{l}41^{*} \\
23^{*} \\
20 \\
20\end{array}$ & $\begin{array}{r}3 \\
1 \\
3\end{array}$ & $\begin{array}{r}3 \\
1 \\
1\end{array}$ & $\begin{array}{r}11 \\
13 \\
1 \\
11\end{array}$ & $\begin{array}{l}6 \\
5 \\
1 \\
3\end{array}$ & $\begin{array}{r}4 \\
5 \\
3\end{array}$ & $\begin{array}{r}14 \\
14 \\
1 \\
14\end{array}$ & $\begin{array}{r}32 \cdot 5 \\
32 \cdot 5 \\
2 \cdot 5 \\
32 \cdot 5\end{array}$ \\
\hline & Totals & 7 & 5 & 36 & 15 & 12 & 43 & 100 \\
\hline
\end{tabular}

Eight cases were associated with dental sepsis

* Proportional difference not significant: $X^{2}=2 \cdot 51, n=1, P=0 \cdot 1-0 \cdot 2$.

only four bronchitics did not in addition show radiological sinus changes, assuming that these had this examination carried out. This emphasizes the inter-relationship of bronchitis and dental and sinus disease as recently suggested by Joules (1954).

It is clear from this that as regards these types of focal infection we are here dealing with a typical cross-section of the population and cannot claim any special significance for the presence of these incidental abnormalities; if we do, it is necessary to explain why the many others so afflicted do not succumb to uveal inflammation. A possible relationship rests in the postulation of a systemic infection, which again must be viral, sometimes limited to one or other part of the body, sometimes widespread and involving the eye. The primary aetiology of bronchitis is unknown (Fry, 1954; Joules, 1954), but may well be viral (Stuart-Harris, 1954); it is almost certainly not bacterial-the limitations of antibiotic therapy confirm this-and is not generally considered to be allergic. Another possible relationship is that of a parallel infection as frequently seen in herpes febrilis labialis. Duke-Elder (1940) has claimed focal sepsis to be the commonest cause of uveitis, the organisms being streptococci and gonococci usually. The rheumatologists have been quick to point out that if such hypotheses are correct then antibiotics should provide the therapeutic answer (Quinn and Liao, 1950); the eradication of foci of infection in rheumatoid arthritis (Davidson and others, 1949; Empire Rheumatism Council, 1950; Copeman, 1955) and in uveitis (Sorsby, 1951; Vesterdal, 1951) has had no effect on these diseases.

Four of the author's cases received large doses of penicillin because of the presence of focal sepsis; of two " collagenous " types, one later relapsed; of two Group B cases, both later relapsed.

Six cases received full courses of streptomycin and P.A.S. or isonicotinic hydrazide; of five Group D cases, two were uninfluenced, and three cleared up and did not later relapse; one case in Group B remained active.

(6) Seasonal Incidence.-Table X (opposite) gives the frequency of attacks for each group during the two half-year periods October-March and April-September. We see that in Groups A and B the incidence is the same for the milder months of the year as for the more severe.

The effect of climatic conditions on rheumatoid diseases has been widely studied. They are undoubtedly rarer in tropical and subtropical countries, but it is difficult 
TABLE $X$

SEASONAL INCIDENCE OF UVEITIS ATTACKS

\begin{tabular}{c|c|c|c|c}
\hline \multirow{2}{*}{ Group } & \multicolumn{2}{|c|}{ October to March } & April to September & Total Attacks \\
\cline { 2 - 4 } & No. & $\%$ & & \\
\hline A & 61 & $49^{*}$ & 64 & 125 \\
B & 96 & $48^{*}$ & 106 & 202 \\
C & 5 & 36 & 95 & 14 \\
D & 91 & 58 & 65 & 156 \\
\hline Totals & 253 & 51 & 244 & 497 \\
\hline
\end{tabular}

* The proportions for Groups A and B show no significant difference $(P>0.05)$

to say whether this is a racial difference, or in some way related to varying degrees of industrialization. The author saw only one case of uveitis of a primary type during his practice as ophthalmologist to the government of Cyrenaica. In a temperate island climate, it is probably true to say that climatic influences do not vary significantly enough to be reflected in any fluctuation of the attack rate of rheumatoid disease. This is, of course, not true for streptococcal infection and rheumatic fever (Coburn and Young, 1949; Copeman, 1955), but we have seen that uveitis is rarely associated with the latter (Duke-Elder, 1940).

We should likewise expect a greater frequency of herpetic and other viral disease in the colder or wetter months, but this does not obtain in Group B. (The summers concerned, however, happened to be wet and cold.) The attack frequencies are shown in Table XI and the Figure (overleaf).

TABLE XI

ATTACK FREQUENCIES BY SEASON

\begin{tabular}{c|c|c|c|c|c|c|c|c|c|c|c|c|c|c}
\hline \multicolumn{2}{c|}{ Group } & Jan. & Feb. & Mar. & Apr. & May & June & July & Aug. & Sept. & Oct. & Nov. & Dec. & Totals \\
\hline A & No. & 10 & 7 & 12 & 10 & 15 & 8 & 12 & 13 & 6 & 6 & 14 & 12 & 125 \\
\hline & $\%$ & 8 & $5 \cdot 6$ & $9 \cdot 6$ & 8 & 12 & $6 \cdot 4$ & $9 \cdot 6$ & $10 \cdot 4$ & $4 \cdot 8$ & $4 \cdot 8$ & $11 \cdot 2$ & $9 \cdot 6$ & 100 \\
\hline \multirow{2}{*}{ B } & No. & 17 & 12 & 15 & 19 & 16 & 14 & 18 & 19 & 20 & 17 & 15 & 20 & 202 \\
\hline C & $\%$ & $8 \cdot 5$ & 6 & $7 \cdot 5$ & $9 \cdot 5$ & 8 & 7 & 9 & $9 \cdot 5$ & 10 & $8 \cdot 5$ & $7 \cdot 5$ & 10 & 100 \\
\hline No. & 2 & 1 & - & 3 & 1 & - & 1 & 3 & 1 & 1 & 1 & - & 14 \\
\hline D & No. & 16 & 10 & 14 & 10 & 16 & 13 & 7 & 8 & 11 & 27 & 13 & 11 & 156 \\
\hline Totals & $\%$ & $10 \cdot 7$ & $6 \cdot 7$ & $9 \cdot 3$ & $6 \cdot 7$ & $10 \cdot 7$ & $8 \cdot 7$ & $4 \cdot 7$ & $5 \cdot 3$ & $7 \cdot 3$ & 18 & $8 \cdot 7$ & $7 \cdot 3$ & 100 \\
\hline & No. & 45 & 30 & 41 & 42 & 48 & 35 & 38 & 43 & 38 & 51 & 43 & 43 & 497 \\
\hline
\end{tabular}

The behaviour of Groups A and B is rather similar save that the frequency of A cases reaches its ebb in September-October, whilst the B cases are highest at this period. Group B reaches the highest levels in April, September, and December ; Group A in May, August, and November. Temperature and precipitation graphs for Southampton are shown also for comparison (Figure). We may note, however, that scarlet fever notification is at its lowest in the 32 nd-38th weeks of the year, i.e. August-September, one month before the Group A cases are lowest. It is remarkable that the local viral Group B cases which are so frequently associated 


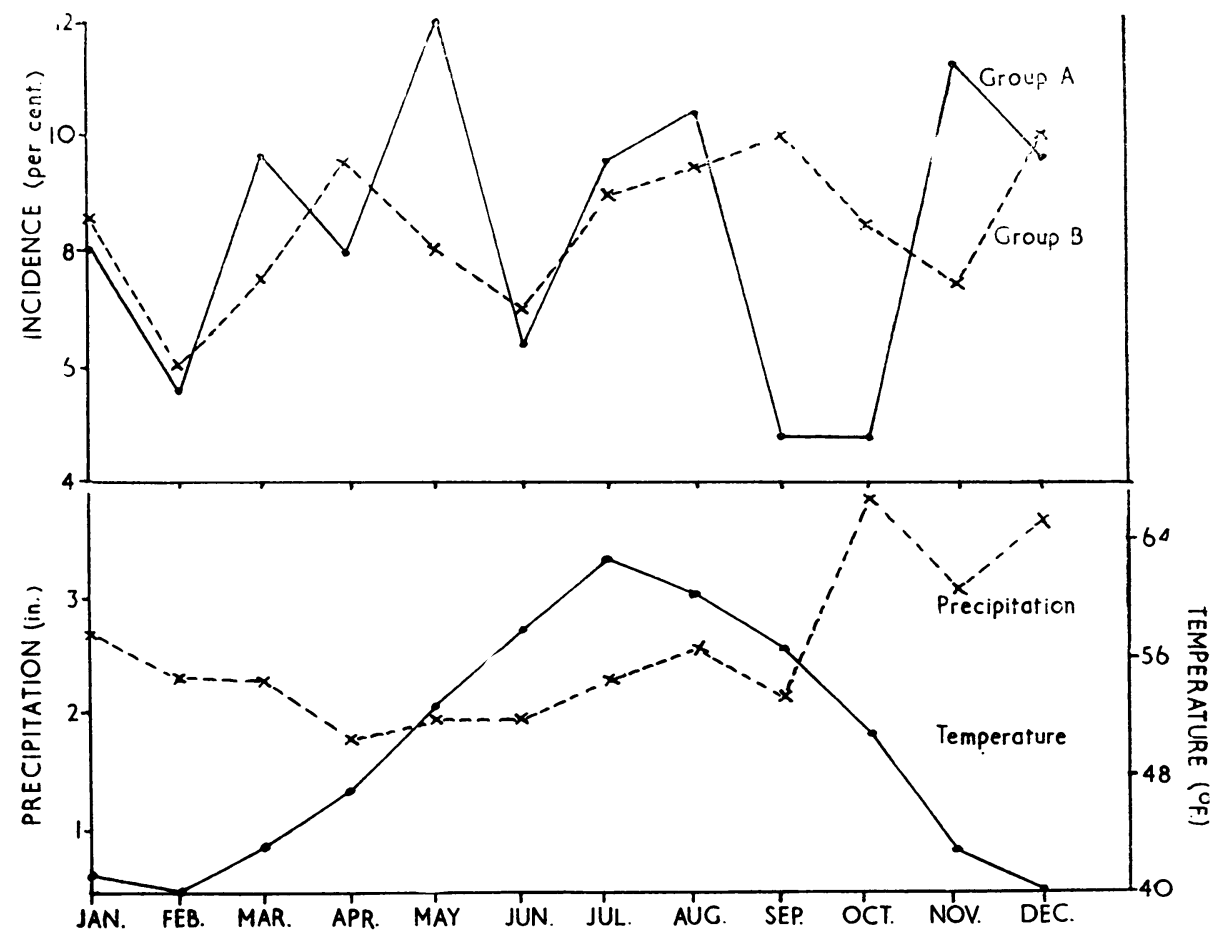

FIGURE.-Attack-frequencies in Groups A and B, with average monthly temperature and precipitation for Southampton.

with acute respiratory infection, should show their minimum in February, when pneumonia, influenza, and whooping-cough notifications are at their highest.

(7) Recurrence Rates (Table XII).-We see that there is a high recurrence rate (33-47 per cent. of patients) in all groups. This is not surprising as all the viral and rheunatic conditions considered are notorious in this respect.

TABLE XII

RECURRENCE RATES

\begin{tabular}{|c|c|c|c|}
\hline Group & $\begin{array}{l}\text { No. of Patients } \\
\text { with More than } \\
\text { One Attack }\end{array}$ & $\begin{array}{l}\text { Per cent. } \\
\text { of Total }\end{array}$ & Significance \\
\hline $\begin{array}{l}\mathrm{A} \\
\mathrm{B}\end{array}$ & $\begin{array}{l}31 \\
45\end{array}$ & $\left.\begin{array}{l}47 \\
35\end{array}\right\}$ & \multirow[t]{2}{*}{$\begin{array}{l}\text { Not Significant } \\
X^{2}=1 \cdot 96, n=1 \\
P=0 \cdot 1-0 \cdot 2\end{array}$} \\
\hline $\begin{array}{l}\text { C } \\
\text { D }\end{array}$ & $\begin{array}{r}6 \\
41\end{array}$ & $\begin{array}{l}40 \\
33\end{array}$ & \\
\hline Total & 123 & 37 & \\
\hline
\end{tabular}

(8) Frequency of Ocular Hypertension.-The number and percentage of patients in each group who at any time suffered a rise of ocular tension are given in Table XIII (opposite). We see that the frequency is much greater in Group B cases. It is 
suggested that ocular hypertension in these cases may be "paretic" in mechanism rather than inflammatory, the rise in tension often being out of proportion to the degree of inflammation, and consequent on the "neurotrophic" spread of the virus (Kalt, 1949).
TABLE XIII

FREQUENCY OF RAISED OCULAR TENSION

\begin{tabular}{|c|c|c|c|}
\hline Group & No. & Per cent. & Significance \\
\hline $\begin{array}{l}\text { A } \\
\text { B }\end{array}$ & $\begin{array}{r}6 \\
32\end{array}$ & $\left.\begin{array}{r}9 \\
25\end{array}\right\}$ & \multirow[t]{2}{*}{$\begin{array}{r}\text { Significant: } \\
X^{2}=6 \cdot 14, n=1 \\
P=0.01-0.02\end{array}$} \\
\hline $\begin{array}{l}\text { C } \\
\text { D }\end{array}$ & $\begin{array}{r}1 \\
10\end{array}$ & $\begin{array}{l}7 \\
8\end{array}$ & \\
\hline Total & 49 & 15 & \\
\hline
\end{tabular}

(9) Other Associations (Table XIV).--There are no significant differences in the proportions for Groups A and B for any of the above factors ( $P$ always $>0 \cdot 05)$.

We have already considered the question of raised output of corticosteroids in myxoedema; we may now note the presence of this state in a number of cases in Groups A and B. An association with coryza is commoner in Group B than in Group A, as we expected, but not significantly so.

TABLE XIV

\section{MISCELLANEOUS ASSOCIATIONS}

\begin{tabular}{|c|c|c|c|c|c|c|c|c|c|}
\hline Group & Myxoedema & $\begin{array}{c}\text { Coryza } \\
\text { per } \\
\text { cent. }\end{array}$ & $\begin{array}{l}\text { Urinary } \\
\text { infection } \\
\text { per cent. }\end{array}$ & $\begin{array}{c}\text { Skin Lesions } \\
\text { not Zoster } \\
\text { per cent. }\end{array}$ & $\begin{array}{c}\text { Herpes } \\
\text { Zoster } \\
\text { per } \\
\text { cent. }\end{array}$ & $\begin{array}{c}\text { Tonsil- } \\
\text { litis }\end{array}$ & Anaemia & $\begin{array}{c}\text { Positive } \\
\text { Wassermann } \\
\text { Reaction }\end{array}$ & Diabetes \\
\hline $\begin{array}{l}\mathbf{A} \\
\mathbf{B} \\
\mathbf{C} \\
\mathbf{D}\end{array}$ & $\begin{array}{l}4 \\
3(7 \%) \\
0 \\
0 \\
0\end{array}$ & $\begin{array}{c}7 \cdot 6 \\
14 \\
0 \\
12\end{array}$ & $\begin{array}{c}1 \cdot 5 \\
3 \\
* \\
2\end{array}$ & $\begin{array}{c}1 \cdot 5 \\
3 \\
6 \\
1\end{array}$ & $\frac{-}{-}$ & $\frac{\overline{2}}{1}$ & $\begin{array}{l}2(3.5 \%) \\
5(4 \%) \\
\frac{1}{1}\end{array}$ & $\frac{1}{2}$ & $\frac{-}{3}$ \\
\hline Total & $2(2 \%)$ & 11 & 2 & 2 & 2 & 3 & 8 & 5 & $3(1 \%)$ \\
\hline
\end{tabular}

Urinary infection was found or known to have existed in a small percentage in each group (non-specific, six; gonococcal, one; leptospiral, 1), as were skin lesions (scleroderma, one; erythema multiforme, three; erythema nodosum, one; eczema, two) with the exception of herpes zoster which was found only in Group B. An association with tonsillitis was found in only three cases-none of these in the rheumatic group. A degree of anaemia with haemoglobin below 80 per cent. and red cells less than 5 million per c. mm. was established in only eight cases, only two of which belonged to the "collagenous" group. As anaemia is considered an index of activity in rheumatoid diseases, this finding is difficult to explain. Again, only two cases in the whole series had a white cell count greater than 10,000 per c. mm.-and one of these was a chronic leukaemic. Only five patients had a positive Wassermann reaction, and in only one of these was the uveitis considered to be syphilitic. Only three were proved diabetics (all in Group D) - this 1 per cent. probably being a fair proportion among hospital patients of all types. One patient gave a history of infectious hepatitis, one of colitis, one of old Pott's disease, one of perinephric abscess; two were suffering from Salmonella gastroenteritis. Eight patients in the "collagenous" group had previously suffered non-specific corneal ulceration, and five in the local viral Group B had evidence of 
rheumatoid disease. This correlation of collagenous and herpetic disease has been noted by Hollenhorst and Henderson (1951). If we take 2 per cent. to be the incidence of all types of rheumatoid disease in the population of the U.K. (Kellgren and others, 1953; Conybeare, 1954) we might expect two or three of the Group B patients to be affected. If however, we bear in mind the fallacy recognized by Berkson (1946), we shall be reluctant to attach great importance to these figures.

\section{(10) Therapy}

Antibiotics.-We have already considered the use of antibiotics.

Old Tuberculin.-We may next deal with the therapeutic use of old tuberculin in uveitis, if only largely to condemn it. Its popularity varies widely from clinic to clinic and from year to year, depending on the particular clinician's view of the place of the tubercle bacillus in uveal disease. Let us now judge its merits solely on its results.

Fifteen of our cases were considered to be tuberculous by the responsible surgeon, this diagnosis being based roughly on the criteria of Woods (1951b) and therefore purely presumptive. None had evidence of any active tuberculosis. Table XV depicts the grouping (according to the author's premises) and history of these cases.

TABLE XV

RESULTS OF OLD TUBERCULIN THERAPY

\begin{tabular}{ccccc}
\hline Group & No. & Controlled & Not Controlled & Relapsed \\
\hline A & 1 & 1 & -2 & 1 \\
B & 6 & 4 & $\frac{2}{3}$ & $\frac{4}{3}$ \\
C & -8 & -5 & 5 (33 per cent.) & 8 (53 per cent. $)$ \\
\hline D & 15 & 10 &
\end{tabular}

* One of the relapsing cases in Group $\mathrm{D}$ had a second course of old tuberculin and had not relapsed again $(2$ years later).

As none could be considered granulomatous, the Group C line is empty. Seven were of a chronic low-grade type with episodic flares; five of these continued on their courses uninterrupted, two quietened but relapsed again a short while later. The remaining eight cases were of typical acute anterior uveitis, which rapidly cleared up; six of these later relapsed. Thus only two patients could possibly be said to have benefited by the treatment. No further comment is necessary.

Cortisone or Hydrocortisone.

(a) Dosage.-The majority of cases of predominantly anterior uveitis were treated only locally, i.e. by subconjunctival injections, $0 \cdot 5$ per cent. drops, or 1 per cent. ointment.

The first was given two or three times a week in doses of 10 to $25 \mathrm{mg}$., the second by 1-, 2-, or 3-hourly instillation, the third by 4-hourly inunction.

A number of anterior cases not responding well, and the predominantly posterior uveal cases, were treated orally, the following schedule being employed:

100-150 mg. daily for 5 days; then $50-100 \mathrm{mg}$. daily for 5 days; then $25-50 \mathrm{mg}$. daily for

5 days; in divided doses. Maintenance doses of $25-50 \mathrm{mg}$. a day were sometimes used for further periods.

Most cases were hospitalized for systemic treatment and the usual precautions and investigations were undertaken. 
(b) Selection of Cases.-During the first year of this investigation, cortisone was difficult to obtain and was used only in a small number of cases at this hospital. No special selection was employed, but possibly the more intense and hypertensive cases had first claim (following the reports of Blake and others, 1950, and Crawford, 1951). In the second year, the drug was fairly freely available, and was used almost indiscriminately in all cases of uveitis. In the third and last year, greater caution was employed, and there was a tendency to avoid the exhibition of this drug in cases of possible viral or tuberculous aetiology. The relatively few cases treated by hydrocortisone are not considered separately.

(c) Criteria of Response.-It is difficult in a self-limiting condition such as uveitis to determine any yard-stick with which the response to treatment may be assessed. As cortisone is non-specific and acts purely symptomatically (Woods and Wood, 1950; Copeman, 1955; Hogan and others, 1955), it cannot be expected to prevent relapse, so consideration of the relapse rate is ruled out at once. We are left with the effect on the visual apparatus and anatomy of the eye, and the duration of the uveitis. To some extent the former depends on the latter. As the mensuration and assessment of the former is by its multipartite nature resistant to classification and comparison, we must adopt the latter as our criterion.

Duration of disease was measured from the beginning of the 3-year period, from the first time cortisone was used, or from the onset of the particular attack of uveitis. The attack was considered concluded when:

(i) No fresh keratic precipitates were noted.

(ii) No cells were seen in the anterior chamber and flare was minimal.

(iii) No oedema or haemorrhages or signs of spread were apparent in the chorio-retinal lesions.

(d) Results.-The average duration of all attacks is shown in Table XVI for Groups A, B, and C, irrespective of any kind of treatment. The total number of attacks for each group in Tables XVI, XVII, and XVIII varies from those in Tables X and XI owing to:

(i) Doubt in some chronic cases as to the exact month of onset.
TABLE XVI

DURATION OF ATTACKS PER EYE, ALL CASES (Weeks)

\begin{tabular}{c|c|c|c}
\hline Group & Average Duration & S.D. & No. of Attacks \\
\hline A & $11 \cdot 48$ & $18 \cdot 07$ & 126 \\
B & $13 \cdot 21$ & $22 \cdot 8$ & 189 \\
C & $34 \cdot 72$ & $42 \cdot 6$ & 25 \\
\hline
\end{tabular}

Average Duration $\left\{\begin{array}{l}\text { Group B-A }=1.73 t=0.75 P>0.05 \\ \text { Group } C-B=21.51 \quad t=2.48 P<0.05 \\ \text { Group } C-A=23.24 t=2.68 P<0.01\end{array}\right.$

TABLE XVII

\section{DURATION OF ATTACKS (WEEKS), ALL CASES, COUNTING EYES, WITH AND WITHOUT CORTISONE}

\begin{tabular}{|c|c|c|c|c|c|c|}
\hline \multirow{2}{*}{ Group } & \multirow{2}{*}{$\begin{array}{l}\text { Number of } \\
\text { Attacks }\end{array}$} & \multicolumn{2}{|c|}{ Average Duration } & \multirow{2}{*}{$\begin{array}{l}\text { Average } \\
\text { Difference }\end{array}$} & \multirow{2}{*}{$t$} & \multirow{2}{*}{$P>$} \\
\hline & & $\begin{array}{l}\text { Without } \\
\text { Cortisone }\end{array}$ & $\begin{array}{c}\text { With } \\
\text { Cortisone }\end{array}$ & & & \\
\hline $\begin{array}{l}\text { A } \\
\mathbf{B} \\
\mathbf{C} \\
\mathbf{D} \\
\end{array}$ & $\begin{array}{r}125 \\
189 \\
25 \\
168 \\
\end{array}$ & $\begin{array}{r}8 \cdot 97 \\
12 \cdot 63 \\
47 \cdot 09 \\
13 \cdot 23\end{array}$ & $\begin{array}{l}14 \cdot 53 \\
13 \cdot 76 \\
25 \\
16 \cdot 65\end{array}$ & $\begin{array}{r}5 \cdot 56 \\
-1.13 \\
+22.09 \\
-3.42\end{array}$ & $\begin{array}{l}1 \cdot 3 \\
0 \cdot 3 \\
1 \cdot 4 \\
-\end{array}$ & $\begin{array}{c}0.05 \\
0.05 \\
0.05 \\
-\end{array}$ \\
\hline Total & 508 & $13 \cdot 32$ & $15 \cdot 48$ & $-2 \cdot 16$ & $1 \cdot 1$ & 0.05 \\
\hline
\end{tabular}


TABLE XVIII

DURATION OF ACTIVITY WITH OR WITHOUT CORTISONE (self-controlled series)

\begin{tabular}{|c|c|c|c|c|c|c|c|}
\hline \multirow{2}{*}{ Group } & \multirow{2}{*}{$\begin{array}{l}\text { Number } \\
\text { of Cases }\end{array}$} & \multicolumn{2}{|c|}{ Average Duration } & \multirow{2}{*}{$\begin{array}{c}\text { Average } \\
\text { Difference }\end{array}$} & \multirow[b]{2}{*}{$t$} & \multirow[b]{2}{*}{ D. of $\mathrm{f}$. } & \multirow[b]{2}{*}{$P>$} \\
\hline & & $\begin{array}{l}\text { Without } \\
\text { Cortisone }\end{array}$ & $\begin{array}{c}\text { With } \\
\text { Cortisone }\end{array}$ & & & & \\
\hline A & 12 & $5 \cdot 53$ & $8 \cdot 96$ & $-3 \cdot 43$ & 1 & 11 & 0.05 \\
\hline B & 12 & 6 & $7 \cdot 62$ & $-1 \cdot 62$ & $1 \cdot 3$ & 11 & 0.05 \\
\hline $\mathrm{C}$ & 1 & $8 \cdot 0$ & $3 \cdot 5$ & $\therefore 4 \cdot 5$ & $-\ldots$ & - & - \\
\hline $\mathrm{D}$ & 8 & $5 \cdot 7$ & 6.2 & 0.5 & - & - & -- \\
\hline Total & 33 & $5 \cdot 81$ & $7 \cdot 64$ & $-1 \cdot 83$ & $1 \cdot 4$ & 32 & $0 \cdot 05$ \\
\hline
\end{tabular}

(ii) Default or other loss of some patients making assessment of duration impossible.

We see that the average duration of attacks in Group B exceeds that in Group A by 1.73 weeks, whilst that in Group C exceeds Group B by 21.51 weeks. Standard deviations are indicated; with these we may compute the variances, the standard errors of difference, and thence Student's $t$. Tables for this factor show that there is no significant difference between the duration of attacks in Groups A and B, $(P>0.05)$ yet there is one between Groups B and $C(P<0 \cdot 05)$ and between Groups $A$ and $C(P<0 \cdot 01)$. This establishes the relatively chronic nature of Group $C$ uveitis.

Table XVII also shows that cortisone treatment prolongs the duration of disease on the average in Groups A, B, and D, but shortens it in Group C. Statistical analysis, using Student's $t$ test, again shows no significant difference between the duration of activity with or without cortisone for Groups A, B, or C, or for the total number of cases.

It might be argued that the cases are not strictly comparable in the treated and untreated series; $\odot . g$. cortisone might have been preferentially given to chronic or intractable cases, or to glaucomatous cases, in the early stages of its use in this hospital, or to non-granulomatous cases later, being withheld from those of a possibly viral nature. We have therefore taken the records of patients with recurrent uveitis treated on one or more occasions with and on other occasions without cortisone, and grouped the attacks accordingly; thus the patients act as their own controls. 33 such patients were traced and their history shown in Table XVIII.

Duration is less for attacks not treated with cortisone, considering all attacks, or those of cases grouped A, B, or D separately. In Group C cases the attacks showed shorter duration when so treated. Applying Student's $t$ analysis, however, we find none of these differences to be significant $(P$ always $>0 \cdot 05)$. Thus cortisone had no significant effect on the duration of the attack in any of our groups.

These results are contrary to those recorded in most previous publications, but the difference may derive from the excessive selectivity and lack of controls shown by these studies, combined with an absence of statistical analysis. In " collagenous" diseases, properly conducted surveys have already revealed the dubious value of these drugs (Medical Research Council and American Heart Association Report, 1955; Medical Research Council and Nuffield Foundation Report, 1954; West and Newns, 1953).

Considering our groups in turn, we might expect cortisone to be beneficial in Group A, of doubtful value in Group C (Woods, 1952; Hogan and others, 1955; etc.), and possibly dangerous in Group B. In general, treatment should prove of little value. This is borne out by our results.

\section{Summary}

(1) Three associational groupings in uveitis are described, and the author's cases are classified accordingly into four groups: 
(A) Systemic disease of the collagenous or rheumatic type.

(B) Local (ocular) viral infection.

(C) Systemic and ocular granulomatous disease.

(D) Other cases.

(2) Investigational analysis shows:

(a) A tendency for Group C cases to affect both eyes, but B cases only one, Groups $A$ and $D$ being intermediate.

(b) No significant sex distribution

(c) A single significant age variation in the relative youthfulness of Group C cases. The rarity of uveitis in children is confirmed.

(d) Erythrocyte sedimentation rates lower in Group B than in Groups A or C.

(e) Incidence of focal infection resembling that in the general population. Eye condition not affected by surgical or antibiotic treatment of focal infection.

( $f$ ) No variation in frequency of attacks for any group with the season of the year.

$(g)$ Recurrence rates high in all groups.

(h) Secondary glaucoma more frequent in Group B.

(i) Of other associations, myxoedema, certain urinary and coryzal infections, and certain dermatoses, perhaps unduly frequent. Positive Wassermann reaction, tonsillitis, and abnormal blood picture rare.

(j) Old tuberculin of no value in treatment.

(k) Duration of attacks greater in Group C than in Groups A or B.

(l) Duration of activity of uveitis in any one group or in the whole series not significantly affected by cortisone.

(3) It is felt that this analysis to some extent confirms the validity of the nosology described, and suggests a basis for the organismal aetiology of uveitis. It indicates the worthlessness of much expensive clinical investigation of patients and of their therapeusis, and urges that greater attention be paid to old-fashioned history-taking and clinical study of the patient as a whole.

I am indebted to the Senior Medical Staff of the Eye Hospital and Royal South Hants. Hospital, Southampton, for their encouragement and kindness in giving me access to their cases and records and in permitting me to publish this work.

\section{REFERENCES}

Alvaro, M. E. (1954). Ophthalmologica (Basel), 127, 85.

BAYLISS, R. I. S. (1955). Brit. med. J., 1, 495.

BERKSON, J. (1946). Biomet. Bull., 2, 47.

BERLINER, M. L. (1943). Amer. J. Ophthal., 26, 50.

Blake, E. M., Fasanella, R. M., and Wong, A. S. (1950). Ibid., 33, 1231.

BlegVAd, O. (1941). Acta ophthal. (Kbh.), 19, 219.

Braley, A. E. (1952). Amer. J. Ophthal., 35, 1737. , and AleXander, R. C. (1953). Arch. Ophthal. (Chicago), 50, 147.

BURNET, M. (1954). Brit. med. J., 2, 189.

Cavara, V. (1950). Boll. Oculist., 29, 3.

Coburn, A. F., and Young, D. C. (1949). " "The Epidemiology of Hemolytic Streptococcus". Williams and Wilkins, Baltimore.

Cochrane, A. L., Cox, J. G., and Jarman, T. F. (1952). Brit. med. J., 2, 843.

Cockburn, T. A. (1954). Amer. J. Ophthal., 38, 476.

Conybeare, E. T. (1954). "W.H.O. Expert Committee on Rheumatic Diseases-Appendix to First Report", Annex 2, p. 21. Tech. Rep. Ser. 78. W.H.O., Geneva. 
Copeman, W. S. C. (1955). "Textbook of the Rheumatic Diseases", 2nd. edn. Livingstone, Edinburgh.

CraWford, H. E. (1951). Amer. J. Ophthal., 34, 1320.

Dalrymple-Champneys, W. (1955). Proc. roy. Soc. Med., 48, 13.

Davidson, L. S. P., Duthie, J. J. R., and Sugar, M. (1949). Ann. rheum. Dis., 8, 205.

DogGaRT, J. H. (1949). British Journal of Ophthalmology, 33, 338.

Dubos, R. J. (1951). Bull. N.Y. Acad. Med., 27, 351. (1954). Publ. Hlth Rep. Wash., 69, 365.

Duke-Elder, S. (1940). "Text-book of Ophthalmology", vol. 3, p. 2126 et seq. Kimpton, London.

EMpIRE Rheumatism Council (1950). Brit. med. J., 1, 799.

Feigenbaum, A., Michaelson, I. C., and KoRnblüth, W. (1945). British Journal of Ophthalmology, 29, 389.

FrançoIs, J. (1950). Ann. Oculist. (Paris), 183, 745.

FRY, J. (1954). Brit. med. J., 1, 190.

Gasteiger, H. (1952). Klin. Mbl. Augenheilk., 120, 19.

GUNDERSEN, T. (1936). Arch. Ophthal. (Chicago), 15, 225.

HANSARD, (1952). Quoted in Brit. med. J., 2, 1158.

Hogan, M. J., and CraWford, J. W. (1942). Amer. J. Ophthal., 25, 1059.

-, Thygeson, P., and Kimura, S. (1955). Arch. Ophthal. (Chicago), 53, 165.

Hollenhorst, R. W., and Henderson, J. W. (1951). Amer. J. med. Sci., 221, 211.

Hughes, quoted by A. C. Woods in "Modern Trends in Ophthalmology", Series II (1948), p. 219. Butterworth, London.

JAFFE, N. S. (1950). Amer. J. Ophthal., 33, 571.

Joules, H. (1954). Brit. med. J., 2, 1259.

Kalt, M. (1949). " "Les Uvéites Hypertensives”, pp. 197 et seq., 174 et seq., 166. Masson, Paris.

Kellgren, J. H., Lawrence, J. S., and Aitken-Swan, J. (1953). Ann. rheum. Dis., $12,5$.

Kimura, S. J., Hogan, M. J., and Thygeson, P. (1954). Arch. Ophthal. (Chicago), 51, 80.

Maumenee, A. E., Hayes, G. S., and Hartman, T. L. (1945). Amer.J. Ophthal., $28,823$.

Medical Research Council and American Heart Association (1955). Brit. med. J., $1,555$.

- and NufFIELD Foundation (1954).' Ibid., 1, 1223.

Müller, H. (1950). v. Graefes Arch. Ophthal., 150, 423 (abst.)

QüINN, R. W., and LiAO, S. J. (1950). J. clin. Invest., 29, 1156.

REMKY, H. (1953). Klin. Mbl. Augenheilk., 123, 166.

Ridley, F., and HaRley, D. (1951). In "Systemic Ophthalmology", ed. A. Sorsby, p. 120 et seq. Butterworth, London.

Rudolph, C. J. (1945). Amer. J. Ophthal., 28, 319.

SANDERS, M. (1942). Arch. Ophthal. (Chicago), 28, 581.

SCHRECK, E. (1951). Ibid., 46, 489.

SELYE, H. (1950). "Stress". ACTA Inc., Montreal.

SORSBY, A. (1951). "Systemic Ophthalmology", p. 118 et seq. Butterworth, London.

SPRINGETT, V. H. (1951). Brit. med. J., 2, 144.

STALKER, R. (1954). Ibid., 1, 1261.

Stewart, A., and Hughes, J. P. W. (1951). Brit. med. J., 1, 899.

StUART-HARRIS, C. H. (1954). Brit. J. Tuberc., 48, 169.

TANNER, O. R. (1954). Arch. Ophthal. (Chicago), 51, 229.

ThYGESON, P. (1943). Ibid., 29, 488, 635.

- (1951). In "Systemic Ophthalmology", ed. A. Sorsby, p. 244 et. seq. Butterworth, London.

(1953). Amer. J. Ophthal., 36, 269.

Vesterdal, E. (1951). Acta ophthal. (Kbh.), 29, 509.

(1952). "Iridocyclitis. Clinical Studies on Aetiology, Pathogenesis, and Therapy with ACTH and Cortisone". Busck, Copenhagen.

WeST, H. F., and NeWNS, G. R. (1953). Lancet, 2, 1123.

WILDER, H. C. (1952). Arch. Ophthal. (Chicago), 47, 425.

Woods, A. C. (1947). Amer. J. Ophthal., 30, 257. (1948). In "Modern Trends in Ophthalmology", Series 2, ed. A. Sorsby, p. 211 et seq. Butterworth, London. (1948). Amer. J. Ophthal., 32, 1457.

(1951a). "XVI Concilium ophthalmologicum, 1950. Britannia Acta ". vol. 1, p. 303. B.M.A., London.

(1951b). In “Systemic Ophthalmology", ed. A. Sorsby, pp. 151 et seq., 202 et seq. Butterworth, London. (1952). British Journal of Ophthalmology, 36, 401.

(1953). Arch. Ophthal. (Chicago), 50, 129. , JACOBS, L., WoOD, R. M.. and CoOK, M. K. (1954). Amer. J. Ophthal., 37, 163. - and Wood, R. M. (1950).-Bull. Johns Hopk. Hosp., 87, 482. (1952). Arch. Ophthal. (Chicago), 47, 477. 